K. Lugarić*

\title{
PRIMLJENE DOZE ZRAČENJA ZA IZLOŽENE DJELATNIKE U OPĆOJ BOLNICI
}

UDK 614.253.5:613.648.4

PRIMLJENO: 3.2 .2017 .

PRIHVAĆENO: 20.12.2017.

\begin{abstract}
SAŽETAK: Prilikom obavljanja svakodnevnih radnih zadataka, pojedini djelatnici opće bolnice izloženi su zračenju od uređaja za dijagnostiku. Svaki neželjeni događaj koji može nastati nepravilnim provođenjem mjera i načela zaštite od zračenja predstavlja društveni gubitak, ali i određeni gubitak za samu ustanovu. Problem ovog istraživanja odnosi se na utjecaj primjene mjera i postupaka zaštite na primljenu dozu zračenja za profesionalno izložene djelatnike. $S$ ciljem prikupljanja i dobivanja podataka te rezultata istraživanja, kao glavna istraživačka metoda odabrana je deskriptivna metoda, dok je izvor istraživanja područje prakse zaštite na radu. Eksperimentalni dio rada temelji se na petogodišnjem praćenju primljenih doza zračenja prema vrsti poslova i radnih zadataka na uzorku od 111 djelatnika. Rezultati istraživanja pokazuju da su primljene doze zračenja za izložene djelatnike u skladu sa zakonskom regulativom, uz uvjet da se svi drže osnovnih mjera zaštite od zračenja i pravila struke.
\end{abstract}

Ključne riječi: ionizirajuće zračenje, djelovanje ionizirajućeg zračenja, zaštita od ionizirajućeg zračenja, doze ionizirajućeg zračenja

\section{UVOD}

Ionizirajuće zračenje je pojam koji se koristi za opis prijenosa energije kroz prostor u obliku subatomskih čestica i elektromagnetskih valova koji imaju sposobnost ionizirati materiju. Proces u kojem atomi gube, katkad i dobivaju, elektrone i tako od neutralnih postaju električki nabijene čestice naziva se ionizacijom.

Izlaganje zračenju od izvora koji su izvan tijela, npr. od rendgenskog uređaja ili kakvog drugog uređaja koji proizvodi ionizirajuće zračenje, naziva se vanjsko ozračenje. Unutarnje ozračenje ljudi nastaje kad radionuklidi uđu u tijelo prehranom, udisanjem ili izravnom apsorpcijom kože.

*Karlo Lugarić, struč. spec. ing. sec., (karlo.lugaric@aquaterm.hr klugaric@gmail.com), Aquaterm d.o.o., Primorska 28, 47000 Karlovac. lako postoje brojne prednosti zračenja, mnogi ljudi boje se njegovog učinka. Ponekad je strah od zračenja opravdan, no najčešće je posljedica neznanja. Većina ljudi upoznata je s osnovama o zračenju, ali to je nedovoljno za zadovoljavajuće odgovore na brojna sumnjičava pitanja. Takvo nepotpuno znanje, kao i u mnogim drugim područjima, često proizvodi još veći strah (Novaković, 2001.).

Kada je u pitanju zaštita čovjekove radne i životne okoline, sve češće je prisutan i problem zaštite od ionizirajućeg zračenja. Čovjek je konstantno izložen ionizirajućim zračenjima koja potječu od prirodnih i umjetnih izvora (Tončev, 1977.).

Suvremena medicina, dijagnostika i liječenje danas su nezamislivi bez upotrebe ionizirajućeg zračenja. Kako bi se otklonili štetni utjecaji ili sveli na prihvatljivi minimum, svako izlaganje 
djelatnika mora biti opravdano uz poduzimanje svih potrebnih zaštitnih mjera. Isto tako, prilikom korištenja izvora ionizirajućeg zračenja potrebno je provoditi mjere zaštite koje se odnose ne samo na djelatnike, već i na pacijente te okoliš (Suljić-Beganović et al., 2015.).

Eksperimentalni dio rada, odnosno provedeno istraživanje, obuhvaća prikaz primljenih doza zračenja po djelatnim kategorijama prema objektivnim uvjetima rada, vrsti poslova i radnim zadacima.

Pomoću tablica i slika prikazani su rezultati istraživanja koji se odnose na stupanj ozračenja izloženih djelatnika koji rade u sferi ionizirajućeg zračenja. Stupanj ozračenja mjeren je osobnim termoluminiscentnim (TLD) dozimetrima i prikazan je u tablicama 1-3 i slikama 2-4. Tablice i slike prikazuju podatke o primljenoj efektivnoj dozi za svakog izloženog djelatnika pod dozimetrijskim nadzorom u kontrolnom intervalu od pet godina, ali i preuzetoj efektivnoj dozi do kontrolnog intervala. Također, pomoću zajedničkih pokazatelja opće bolnice prikazan je broj djelatnika u sferi ionizirajućeg zračenja, ukupno primljena efektivna doza za kontrolni interval prema službama/odjelima, dobi, spolu i zanimanju te prosječno primljena doza za sve djelatnike u službi/odjelu.

\section{DJELOVANJE IONIZIRAJUĆEG ZRAČENJA}

Prolaskom zračenja kroz materiju dolazi do ionizacije, pri čemu se energija zračenja prenosi na elektrone u atomima materije čime zračenje slabi dok ne nestane ili mu prodorna moć ne oslabi da više nije štetno. Interakcija zračenja s biološkim materijalom može se promatrati na temelju fizičkih i kemijskih načela, a učinci zračenja dijele se na primarni i sekundarni efekt. Ozračenje izaziva molekularne promjene, a posljedica takvih poremećaja su biokemijske promjene te rane fiziološke promjene. Isto tako, postoji mogućnost da dođe do mutacije - genetske i somatske. Prve izazivaju promjene na potomstvu, a potonje su individualne tjelesne promjene (rak, leukemija, prijevremeno starenje i sl.). Stupanj oštećenja ovisi o: vrsti i količini zračenja kojoj je materija izložena, gdje se materija nalazi u trenutku zračenja, trajanju zračenja, bioloških karakteristika materije itd.

Prilikom čestičnog zračenja alfa i beta-čestice imaju masu te se prolazom između atoma sudaraju s njim i pritom dio svoje kinetičke energije predaju elektronima. Broj ioniziranih atoma se povećava, a njihova energija se smanjuje. Kad predaju svu energiju, čestice se zaustave i utope u materiji. Alfa-česticu mogu zaustaviti list papira, koža ili sloj zraka. Beta-čestica ima manju masu te se rjeđe sudari s materijom, ali joj je zbog toga potreban dulji put da sudarima preda svu svoju kinetičku energiju prije nego se zaustavi. Znatno veću prodornost od alfa i beta-čestica posjeduju gama čestice (slika 1). To su visoko energetski fotoni s jako kratkim valovima, manjim od 0,5 nm. Gama-zračenje je najprodornija vrsta zračenja, ali mu je jačina ionizacije manja od alfa i beta-čestica (Tončev, 1977.).

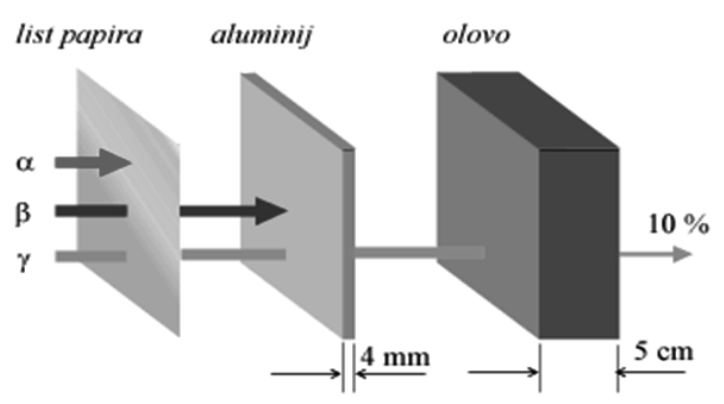

Slika 1. Prodornost alfa, beta i gama-čestice

Figure 1. Acuteness of alpha, beta and gamma particle

\section{Kemijski učinci}

Osnovni element svih živih bića je stanica. Ovisno o vrsti tkiva, veličina stanice varira. Nabijene čestice i elektromagnetsko zračenje, pri prolazu kroz materijal, djeluju na elektrone i provode ionizaciju otkidajući ih od atoma i molekula za koje su vezani. Ioniziraju se molekule tijela i one postaju aktivne u kemijskom smislu te počinju djelovati na organske makromolekule tijela. Upravo na taj način zračenje može dovesti do mijenjanja, oštećenja ili razaranja tih mole- 
kula. To uzrokuje nastanak kompleksnih fizikalno-kemijskih procesa i bioloških promjena čiji je rezultat biološka reakcija na zračenje. Biološka reakcija je proporcionalna količini energije zračenja koja je apsorbirana u tijelu (Turner, 2007.).

\section{Biološki učinci}

Pobudom ili ioniziranjem atoma u živoj stanici zračenje djeluje na životne funkcije stanice, a samim time i na živa tkiva, organe i organizme (Hebrang i Klarić-Čustović, 2007). Ukupni učinci zračenja na žive jedinke dijele se na somatske i genetske. Ovisno o dozi, posljedice somatskog učinka u ljudi mogu biti poremećaji krvne slike, oštećenje kože, ali i dugoročne posljedice kao što su leukemija, razne vrste zloćudnih bolesti, smanjenje plodnosti te posljednično skraćenje životnog vijeka. Učinak velikih doza na čovjeka ovisi o ritmu ozračivanja (kratko ili dugo, jednokratno ili višekratno).

Biološki učinci zračenja mogu se promatrati na različitim razinama biološke organizacije: na razini cijele populacije, na razini organizma, tkiva ili organa, na staničnoj razini, na razini struktura manjih od stanice i na molekularnoj razini. Na razini populacije se djelovanjem zračenja pojavljuju promjene genskih karakteristika nastale zbog genskih i kromosomskih mutacija pojedinih jedinki vrste. Prema pogibeljnosti, biološki učinci zračenja dijele se u dvije skupine: determinističke (nestohastičke) i stohastičke.

\section{Deterministički (nestohastički) učinci zračenja}

Deterministički (nestohastički) učinci zračenja pojavljuju se onda kada je primljena dostatno velika doza i za njih postoji prag. To znači da se za nestohastičke učinke može propisati sigurnosna granica.

Primjeri determinističkih učinaka su nemaligne ozljede kože (eritemi), smanjenje broja stanica u koštanoj srži, fibroze, zamućenje očne leće, akutni radijacijski sindrom itd. Ovisno o pragu doze i razdoblju nakon ozračivanja, različiti su deterministički učinci zračenja.

Radijacijski sindrom, odnosno akutna radijacijska bolest, ima veliki broj oblika koji ovise o mnogim čimbenicima poput vrste zračenja, primljene doze, duljine vremena izlaganja zračenju, osjetljivosti pojedinih organa, tkiva ili cijelog organizma na zračenje, dobi, spolu itd (Brumen, Franić i Garaj-Vrhovac, 2002.).

\section{Stohastički učinci zračenja}

U svojoj knjizi Turner (2007.) tvrdi da su stohastički učinci statistički izvjesni kao što im ime implicira, ali im je razdioba slučajna.

Smatra se da je vjerojatnost pojavljivanja stohastičkih učinaka zračenja razmjerna dozi bez praga. To znači da ne postoji neka minimalna doza ispod koje se takvi učinci ne pojavljuju. Drugim riječima, bilo koji iznos doze - bez obzira na to koliko ona bila malena - povećava rizik koji donose stohastički učinci. Upravo ta hipoteza čini osnovu ALARA (As Low As Reasonably Achiveable) načela prema kojem izlaganje zračenju mora biti onoliko nisko koliko se to na razuman način može postići.

Vjerojatnost da se takvi učinci pojave izražava se kao rizik koji je proporcionalan primljenoj dozi.

Pod stohastičkim učincima podrazumijevaju se genetička oštećenja i pojava raka.

Postojeće znanje o zdravstvenim učincima zračenja zasniva se na informacijama prikupljenim iz epidemioloških studija populacija izloženih visokim dozama zračenja. Općenito, epidemiološke studije koje bi sa sigurnošću upozorile na odnos između doze i rizika na niskim dozama morale bi trajati barem koliko i prosječan životni vijek, a zbog izrazito malih učinaka zahtijevale bi velik broj ispitanika. Zbog nepraktičnosti i goleme cijene, takve studije praktički su isključene. Dok jedni smatraju da su rizici preniski, mnogi stručnjaci smatraju da su previsoki. Postoje stručna mišljenja da male doze zračenja nisu štetne, nego čak mogu djelovati blagotvorno. Takva mišljenja su demonstrirana u nekim pokusima na staničnoj razini (cellular studies). Hipoteza je poznata pod nazivom radijacijska hormeza (hormesis učinak) ili adaptivni odziv. 
Učinci malih doza ne mogu se mjeriti s dostatnom statističkom pouzdanošću. Stoga je za procjenu rizika ključno razumijevanje celularnih mehanizama karcinogeneze. Sve to dovodi tzv. linearnu hipotezu u pitanje, po kojoj i pri najmanjim dozama zračenja postoji linearan odnos između doze i njezina učinka, a koji je proporcionalan riziku. Ozbiljni epistemiološki problem nemogućnosti pronalaska štetnih učinaka zračenja pri malim dozama, pri postuliranju LNT hipoteze u važeći sustav zaštite od zračenja, naprosto je ignoriran (Brumen, Franić i Garaj-Vrhovac, 2002.).

\section{ZAŠTITA OD IONIZIRAJUĆEG ZRAČENJA}

Novaković (2002.) navodi kako uporaba izvora ionizirajućeg zračenja može dovesti do nepopravljivih štetnosti, pa je posve razumljivo da je posebno potrebno poduzimanje mjera koje će spriječiti nastanak takvih štetnosti. Dakle, zaštita od ionizirajućeg zračenja predstavlja skup mjera kojima je svrha očuvati život i zdravlje čovjeka kao i njegova okoliša od štetnog djelovanja zračenja.

Srž zaštite od zračenja je primjena suvremenih sredstava i znanja iz ovog područja na način da djelatnicima osigura siguran rad na radnim mjestima te da oni u bilo kojem trenutku ili situaciji ne prime veću količinu zračenja od dopuštene (Tončev, 1977.).

\section{Ciljevi zaštite od zračenja}

Pri obavljanju djelatnosti do kojih dolazi do izlaganja zračenju, potrebno je osigurati da to izlaganje bude opravdano. To su djelatnosti koje čovjek drži toliko korisnim za sebe da je voljan izložiti se riziku koji je s njima povezan. Pritom se taj rizik ne smatra fatalističkim, već se čovjek trudi umanjiti ga ili čak potpuno isključiti. Krajnji cilj je postizanje neto koristi za pojedince i društvo u cijelosti od bilo koje djelatnosti.

Ciljevi zaštite od zračenja su:

- spriječiti determinističke učinke,
- ograničiti pojavu stohastičkih učinaka na najmanju moguću mjeru,

- osigurati da djelatnost s izlaganjem zračenju bude opravdana na način da neto korist prevladava nad štetnim učincima.

\section{Načela zaštite od zračenja}

Međunarodne preporuke za zaštitu od ionizirajućeg zračenja zasnivaju se na sljedećim temeljnim načelima:

- opravdanost djelatnosti - obvezno biti sigurni da će se dobiti veća korist za izložene pojedince ili društvo od štete koju ta izloženost može prouzročiti,

- optimizacija djelatnosti - svako izlaganje mora biti toliko nisko koliko je to moguće postići, uvažavajući društvene i ekonomske čimbenike (ALARA),

- granica doze - niti jedna osoba ne smije primiti dozu iznad utvrđenih gornjih granica izlaganja u danim uvjetima.

Sva tri načela odnose se na zaštitu profesionalno izloženih djelatnika i na zaštitu ostalih osoba (Novaković, 2002.).

\section{REGULATIVA U PODRUČJU ZAŠTITE OD ZRAČENJA}

Znanstvene spoznaje i razne tehničke prijedloge potrebno je zaodjenuti u formu pravnih propisa i na taj način ih učiniti opće obvezatnim.

Na osnovi Zakona o radiološkoj i nuklearnoj sigurnosti, Državni zavod za radiološku i nuklearnu sigurnost (DZRNS) nadležno je tijelo državne uprave Republike Hrvatske za poslove radiološke i nuklearne sigurnosti. DZRNS nadzire uporabu izvora ionizirajućeg zračenja još prije nego potencijalni korisnik nabavi takav izvor. Za dobivanje radnih dozvola potrebno je ispunjavati određene preduvjete i postupke. Nadzor nad provedbom zaštitnih mjera i sankcije u slučaju kršenja propisa u nadležnosti su DZRNS-a.

Također, određena su načela i mjere zaštite od ionizirajućeg zračenja u svrhu omogućavanja primjerene zaštite pojedinaca, društva i okoliša te od štetnih posljedica ionizirajućeg zračenja i 
omogućavanja sigurnog obavljanja djelatnosti s izvorima ionizirajućeg zračenja.

U skladu s Pravilnikom o granicama ozračenja utvrđene su granice izlaganja djelatnika koji obavljaju djelatnosti s ionizirajućim zračenjima:

- efektivna doza izloženih djelatnika ne smije u normalnim uvjetima tijekom rada biti veća od $100 \mathrm{mSv}$ u razdoblju od pet uzastopnih godina, uz uvjet da niti u jednoj godini petogodišnjeg razdoblja efektivna doza ne smije biti veća od $50 \mathrm{mSv}$,

- ekvivalentna doza za očne leće izloženih radnika ne smije u normalnim uvjetima rada biti veća od $150 \mathrm{mSv}$ u jednoj godini,

- ekvivalentna doza za podlaktice, šake, stopala ili kožu izloženih radnika ne smije u normalnim uvjetima rada biti veća od $500 \mathrm{mSv}$ u jednoj godini.

Budući da su izloženi djelatnici pod izravnim učestalim i ciljanim nadzorom (dozimetrijskim i zdravstvenim), navedene doze bitno su više od granica koje vrijede za pripadnike pučanstva jer su uvjetovane obavljanjem djelatnosti uz izvore zračenja.

Bitno je napomenuti da su i ove granice još u „sigurnom" području. To znači da se djelatniku jamči da neće imati štetnih posljedica, odnosno da će na vrijeme biti otkrivene i da će se poduzeti potrebne mjere da se otklone. Prije početka školovanja za zanimanja koja uključuju izvore zračenja, bitna je prethodna ocjena zdravstvene sposobnosti potencijalnog djelatnika. Pravilnikom o zdravstvenim uvjetima izloženih radnika i osoba koje se obučavaju za rad s izvorima ionizirajućeg zračenja utvrđeni su zdravstveni uvjeti kojima moraju udovoljavati izloženi pripravnici i izloženi djelatnici prije početka rada i tijekom rada u području izloženosti te učenici i studenti prije početka i tijekom obrazovanja za rad s izvorima ionizirajućeg zračenja, ali i učestalost zdravstvenih pregleda te sadržaj, način i rokovi čuvanja podataka o tim pregledima.

Potrebno je i posebno stručno obrazovanje djelatnika koje uključuje i upoznavanje s mjerama zaštite od zračenja, a ono je utvrđeno Pravilnikom o obrazovanju potrebnom za rukovanje izvorima ionizirajućeg zračenja i primjenu mjera radiološke sigurnosti. Na temelju Zakona o zaštiti na radu i u skladu s Pravilnikom o poslovima s posebnim uvjetima rada, prije početka rada i tijekom samog rada obvezatan je periodički zdravstveni nadzor nad djelatnikom i održavanje kvalitete mjera zaštite za cijelo vrijeme obavljanja djelatnosti. Prema potrebi može se odlučiti da i poslije prestanka rada s izvorima zračenja djelatnik bude i dalje pod nadzorom.

\section{OSOBNA DOZIMETRIJA}

Dozimetrija se može definirati kao mjerenje doze ionizirajućeg zračenja s pomoću odgovarajućih instrumenata - dozimetara. Uspostavljanje numeričkih relacija između doze te fizikalnih, kemijskih i bioloških učinaka koje ta doza izaziva omogućilo je kvantitativno mjerenje doze ionizirajućeg zračenja (Dodig, Ivančević i Popović, 2002.).

Osobna dozimetrija jest određivanje izloženosti zračenju uz vanjsko ozračivanje osoba koje rade s izvorima ionizirajućeg zračenja. Prema Pravilniku o mjerenju osobnog ozračenja, ispitivanja izvora ionizirajućeg zračenja i uvjeta rada te o izvještajima i očevidnicima, djelatnici koji rade s izvorima ionizirajućeg zračenja obvezni su tijekom rada provoditi sve propisane i uobičajene mjere samozaštite od ionizirajućeg zračenja te se koristiti uređajima za mjerenje osobnog ozračivanja.

Dodig, Ivančević i Popović (2002.) zaključili su da je važnost osobne dozimetrije u tome da se samo redovitim i točnim praćenjem izlaganja profesionalnog osoblja može zaključiti je li zaštita od zračenja i metoda rada odgovarajuća.

Osobni dozimetar za utvrđivanje efektivne doze na cijelo tijelo u pravilu se nosi na lijevoj strani prsa, kako bi mogao pokazati izloženost cijelog tijela zračenja.

\section{CILJ ISTRAŽIVANJA}

Cilj istraživanja jest doći do potvrde pretpostavke da su primljene doze izloženih djelatnika u općoj bolnici u sklopu zakonskih i podzakonskih odredbi. 
Do 31. prosinca 1999. godine, s osobnim dozimetrima mjerene su i doze ionizirajućeg prirodnog zračenja, pa su stoga bile daleko više izražene u mikrosievertima $(\mu \mathrm{S} v)$. Od siječnja 2000. godine mjeri se isključivo efektivna doza ionizirajućeg zračenja, pa su od tada doze zračenja mnogostruko smanjene.

\section{METODE ISTRAŽIVANJA I ISPITANICI}

Istraživanje je provedeno u razdoblju od svibnja 2016. godine do rujna 2016. godine. U istraživanju je korištena deskriptivna metoda, odnosno metoda analize dostupne dokumentacije opće bolnice. Pri izradi ovog rada korištena su sredstva i materijali različitih ovlaštenih stručnih tehničkih servisa za stručne poslove zaštite od ionizirajućeg zračenja. Postupak pregleda dokumentacije bio je temeljit. Sva dostupna dokumentacija pregledana je i podaci su korišteni u izradi ovog rada.

Analiza istraživanja sastojala se od prikupljanja, sređivanja i obrade podataka. Podaci su prikupljeni u obliku godišnjih izvještaja o primljenim dozama (ispitivanje osobnog doznog ekvivalenta $\mathrm{Hp}(10))$ za svakog djelatnika koji radi u području ionizirajućeg zračenja. Istraživanje je provedeno u petogodišnjem razdoblju (1.1.2011.-31.12.2015.) kako bi se rezultati eksperimenta mogli smatrati relevantnim.

U općoj bolnici zaposleni su doktori medicine ili specijalizanti različitih grana medicine, inženjeri medicinske radiologije, više i srednje medicinske sestre te ostalo medicinsko i nemedicinsko osoblje. Osobe koje rukuju rendgenskim uređajima imaju rizik u smislu ozračenja. Također, navedeni zaposlenici čija je nazočnost neophodna tijekom uporabe rendgenskog uređaja imaju rizik od ozračenja.
Istraživanje je provedeno na uzorku od ukupno 111 izloženih djelatnika koji svakodnevne radne zadatke izvršavaju u području ionizirajućeg zračenja. Ispitanu skupinu činilo je 50 muškaraca $(45,05 \%)$ i 61 žena $(54,95 \%)$.

Djelatnici Odjela za opće, pravne i kadrovske poslove zaposleni na radnom mjestu "nosača", a koji tijekom rendgenskog pregleda pridržavaju bolesnike i druge osobe koje ne mogu samostalno ostati u potrebnom položaju za pregled, ne smatraju se izloženim djelatnicima. Navedeni djelatnici tijekom boravka u području izloženosti prilikom pridržavanja pacijenata koriste osobni dozimetar.

\section{REZULTATI ISTRAŽIVANJA}

Organizacijska struktura opće bolnice sadrži sljedeće ustrojstvene jedinice koje za obavljanje djelatnosti koriste izvore ionizirajućeg zračenja:

- Odjel za radiologiju,

- Odjel za anesteziologiju, reanimatologiju i intenzivnu medicinu,

- Služba za kirurgiju

- Odjel za dječju kirurgiju,

- Odjel za opću, plastičnu, rekonstrukcijsku i estetsku kirurgiju,

- Odjel za abdominalnu kirurgiju,

- Odjel za vaskularnu kirurgiju,

- Odjel za ortopediju i traumatologiju,

- Odjel za urologiju,

- Odjel za ginekologiju i opstetriciju,

- Odjel centralne operacije i sterlizacije,

- Služba za internu medicinu. 
Tablica 1. Primljene doze za liječnike specijaliste radiologe

Table 1. Received doses for radiology specialists

\begin{tabular}{|c|c|c|c|c|c|c|c|c|c|}
\hline \multirow{2}{*}{ Djelatnik } & \multirow{2}{*}{ Zanimanje } & \multirow{2}{*}{ Spol } & \multirow{2}{*}{$\begin{array}{c}\text { Preuzeta } \\
\text { doza u } \mu S v \\
\text { za razdo- } \\
\text { blje }(01 / 00 \\
-12 / 10)\end{array}$} & \multicolumn{5}{|c|}{$\begin{array}{l}\text { Primljene godišnje doze u } \mu \mathrm{Sv} \text { za kontrolni interval } \\
\qquad(1 / 11-12 / 15)\end{array}$} & \multirow{2}{*}{$\begin{array}{c}\text { Ukupno } \\
\text { primljena } \\
\text { doza u } \\
\mu S v \text { za } \\
\text { kontroln } \\
\text { interval }\end{array}$} \\
\hline & & & & 2011. & 2012. & 2013. & 2014. & 2015. & \\
\hline R-01 & dr. med. & $\check{Z}$ & 1473 & 100 & 10 & 126 & 0 & 0 & 236 \\
\hline $\mathrm{R}-02$ & dr. med. & M & 0 & 30 & - & - & - & 0 & 30 \\
\hline R-03 & dr. med. & M & 880 & 270 & 30 & 0 & 0 & 86 & 386 \\
\hline R-04 & dr. med. & $\check{Z}$ & 1670 & 40 & 130 & 0 & 0 & 0 & 170 \\
\hline R-05 & dr. med. & $M$ & 970 & 700 & 20 & 226 & 0 & 0 & 946 \\
\hline R-06 & dr. med. & Ž & 300 & 20 & - & - & 0 & 0 & 20 \\
\hline R-07 & dr. med. & $\check{Z}$ & 50 & - & - & 0 & 0 & 0 & 0 \\
\hline
\end{tabular}

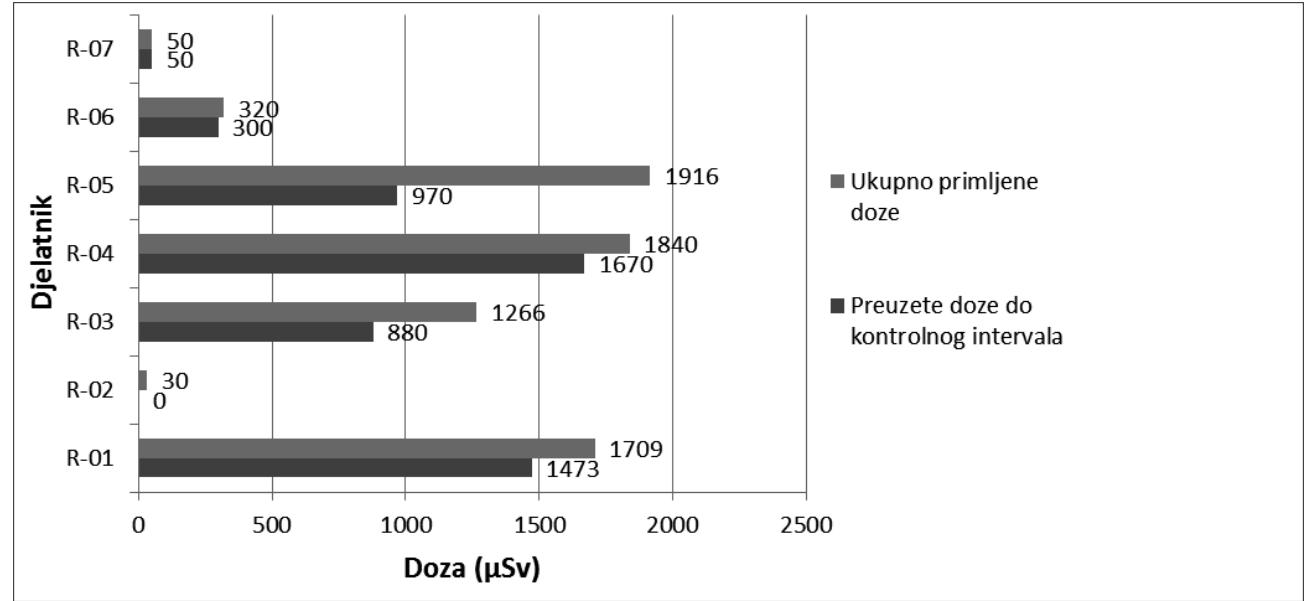

Slika 2. Preuzete doze i ukupno primljene doze za liječnike specijaliste radiologe

Figure 2. Taken doses and total received doses for radiology specialists

Prema Analizi rizika opće bolnice (2015.), s obzirom na narav i vrstu posla, organizaciju radnih postupaka i radni proces, liječnici specijalisti radiologije i inženjeri medicinske radiologije imaju najveći rizik od ozračenja.

Doktor medicine, radiolog asistira pri operativnim zahvatima, provodi dijaskopske pretrage s kontrastnim sredstvima (izvan prostorije) i urografije (unutar prostorije). Doktor medicine, intervencijski radiolog provodi dijagnostičko-terapijske postupke uporabom rendgenskih uređaja kao što su angiografije, balon dilatacije krvnih žila itd., također unutar prostorije. Dok- tor medicine, specijalizant radiologije asistira radiologu pri dijagnostičko-terapijskim postupcima ili ih pod njegovim nadzorom provodi unutar prostorije.

Inženjer medicinske radiologije rukuje rendgenskim uređajima (unutar prostorije), pozicionira pacijenta, u postupcima intervencijske radiologije i koronografije upravlja rendgenskim uređajem unutar prostorije, tijekom selektivne angiografije izvan prostorije. Tijekom rada u operacijskoj sali rukuje rendgenskim uređajem i dijaskopira. 
Tablica 2. Primljene doze za inženjere medicinske radiologije

Table 2. Received doses for medical radiology engineers

\begin{tabular}{|c|c|c|c|c|c|c|c|c|c|}
\hline \multirow[b]{2}{*}{ 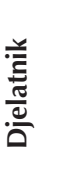 } & \multirow[b]{2}{*}{ 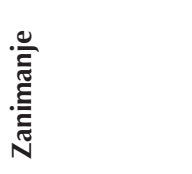 } & \multirow[b]{2}{*}{ के } & \multirow{2}{*}{$\begin{array}{c}\text { Preuzeta } \\
\text { doza u } \mu S v \\
\text { za razdoblje } \\
(01 / 00- \\
12 / 10)\end{array}$} & \multicolumn{5}{|c|}{ Primljene godišnje doze u $\mu$ Sv za kontrolni interval (1/11 - 12/15) } & \multirow{2}{*}{$\begin{array}{c}\text { Ukupno } \\
\text { primljena } \\
\text { doza u } \mu S v \\
\text { za kontroln } \\
\text { interval }\end{array}$} \\
\hline & & & & 2011. & 2012. & 2013. & 2014. & 2015. & \\
\hline R-08 & ing. med. rad. & $\check{Z}$ & 1670 & 50 & 10 & 0 & 0 & 0 & 60 \\
\hline R-09 & ing. med. rad. & $\check{Z}$ & 970 & 60 & 30 & 0 & 147 & 164 & 401 \\
\hline $\mathrm{R}-10$ & ing. med. rad. & M & 830 & 50 & 10 & 0 & 0 & 0 & 60 \\
\hline $\mathrm{R}-11$ & ing. med. rad. & Ž & 1331 & 220 & 10 & 0 & 0 & 0 & 230 \\
\hline $\mathrm{R}-12$ & ing. med. rad. & M & 180 & 50 & 10 & 0 & 0 & 0 & 60 \\
\hline $\mathrm{R}-13$ & ing. med. rad. & M & 1577 & 80 & 20 & 0 & 0 & 0 & 100 \\
\hline $\mathrm{R}-14$ & ing. med. rad. & Ž & 1280 & 40 & 10 & 0 & 0 & 0 & 50 \\
\hline $\mathrm{R}-15$ & ing. med. rad. & M & 970 & 170 & 20 & 182 & 0 & 0 & 372 \\
\hline $\mathrm{R}-16$ & ing. med. rad. & M & 1380 & 130 & 30 & 0 & 0 & 0 & 160 \\
\hline $\mathrm{R}-17$ & ing. med. rad. & M & 0 & - & - & - & - & 120 & 120 \\
\hline $\mathrm{R}-18$ & ing. med. rad. & Ž & 2410 & 180 & 10 & 0 & 0 & 0 & 190 \\
\hline $\mathrm{R}-19$ & ing. med. rad. & $\check{Z}$ & 1710 & 60 & 10 & 0 & 0 & 0 & 70 \\
\hline $\mathrm{R}-20$ & ing. med. rad. & M & 1840 & 140 & 20 & 0 & 0 & 0 & 160 \\
\hline $\mathrm{R}-21$ & ing. med. rad. & Ž & 3110 & 170 & 20 & 0 & 0 & 0 & 190 \\
\hline $\mathrm{R}-22$ & ing. med. rad. & M & 720 & 90 & 10 & 0 & 0 & 0 & 100 \\
\hline $\mathrm{R}-23$ & ing. med. rad. & Ž & 1670 & 30 & 10 & 0 & 0 & 0 & 40 \\
\hline $\mathrm{R}-24$ & ing. med. rad. & M & 1220 & 110 & 20 & 0 & 99 & 123 & 352 \\
\hline $\mathrm{R}-25$ & ing. med. rad. & $\check{Z}$ & 1810 & 80 & 10 & 0 & 0 & 0 & 90 \\
\hline
\end{tabular}

Tablica 3. Zajednički pokazatelji opće bolnice

Table 3. Consolidated indicators of general hospital

\begin{tabular}{|c|c|c|c|c|c|c|c|c|c|c|c|c|c|}
\hline \multirow[b]{2}{*}{ R.B. } & \multirow[b]{2}{*}{ 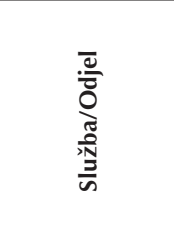 } & \multirow[b]{2}{*}{ 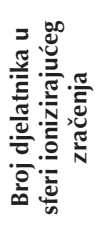 } & \multirow[b]{2}{*}{ 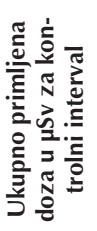 } & \multirow[b]{2}{*}{ 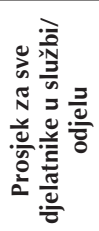 } & \multicolumn{9}{|c|}{ Ukupno primljene doze u $\mu S v$ za kontrolni interval po zanimanju i spolu } \\
\hline & & & & & dr. med. & $M$ & Ž & $\begin{array}{l}\text { ing. med. } \\
\text { rad. }\end{array}$ & $\mathbf{M}$ & $\check{z}$ & $\begin{array}{l}\text { bacc. med. } \\
\text { techn., } \\
\text { med. se- } \\
\text { stra, med. } \\
\text { tehničar }\end{array}$ & $M$ & Ž \\
\hline 1. & Radiologija & 25 & 4593 & 183,7 & $1788 / 7$ & 3 & 4 & 2805/18 & 9 & 9 & - & - & - \\
\hline 2. & Anesteziologija & 22 & 2769 & 125,9 & $2001 / 15$ & 5 & 10 & - & - & - & $768 / 7$ & 1 & 6 \\
\hline 3. & Kirurgija & 26 & 2877 & 110,7 & $2867 / 25$ & 23 & 2 & - & - & - & $10 / 1$ & 0 & 1 \\
\hline 4. & Urologija & 7 & 369 & 52,7 & $289 / 5$ & 3 & 2 & - & - & - & $80 / 2$ & 0 & 2 \\
\hline 5. & Ginekologija & 2 & 40 & 20 & $40 / 2$ & 1 & 1 & - & - & - & - & - & - \\
\hline 6. & Operacija & 19 & 2020 & 106,3 & - & - & - & - & - & - & $2020 / 19$ & 1 & 18 \\
\hline 7. & Interna & 10 & 368 & 36,8 & $232 / 6$ & 4 & 2 & - & - & - & $136 / 4$ & 0 & 4 \\
\hline \multicolumn{2}{|r|}{ Ukupno } & 111 & 13036 & 90,9 & $7217 / 60$ & 39 & 21 & 2805/18 & 9 & 9 & $3014 / 33$ & 2 & 31 \\
\hline
\end{tabular}




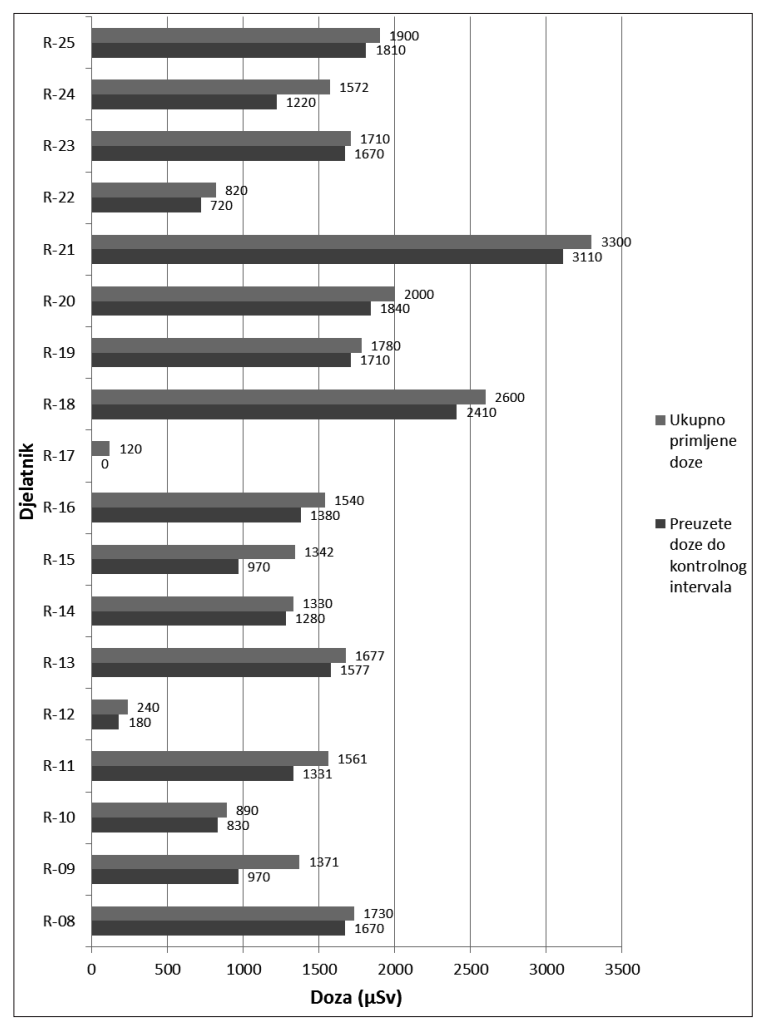

Slika 3. Preuzete doze i ukupno primljene doze za inženjere medicinske radiologije

Figure 3. Taken doses and total received doses for medical radiology engineers

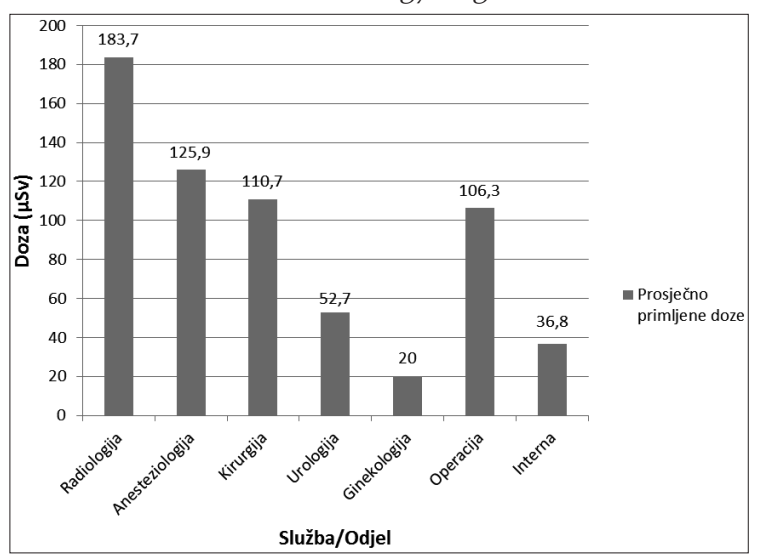

Slika 4. Prosječno primljene doze za svakog izloženog djelatnika po službama i odjelima

Figure 4. Average received doses for every exposed employee by departments and sections

\section{RASPRAVA}

Od ukupnog broja djelatnika opće bolnice pod dozimetrijskim nadzorom najveći broj ispi- tanika svoje radne zadatke obavlja u Službi za kirurgiju (23,4 \%). Zatim slijedi Odjel za radiologiju (22,5 \%), Odjel za anesteziologiju (19,8 \%), Odjel centralne operacije i sterilizacije $(17,1 \%)$ i Služba za internu medicinu (9\%). Odjel za urologiju i Odjel za ginekologiju i opstetriciju čini tek $6,3 \%$ odnosno $1,8 \%$ ispitanika (Tablica 3 ).

Doktori različitih grana medicine čine najveći dio ispitane skupine $(54,1 \%)$, zatim slijede više medicinske sestre, medicinske sestre i medicinski tehničari $(29,7 \%)$, a najmanji dio ispitanika su inženjeri medicinske radiologije $(16,2 \%)$; (Tablica 3).

lako broj ispitanika na Odjelu za radiologiju nije najveći, rezultati prikazani u Tablici 3. pokazuju da je najveća ukupno primljena doza kod djelatnika radiološke struke (4,6 mSv). Očigledna razlika između djelatnika radiološke i neradiološke struke također se očitava i na slici 4. koja prikazuje prosječno primljene doze prema vrsti poslova i radnih zadataka.

Najozračeniji djelatnik u jednoj godini kontrolnog intervala ovog istraživanja je djelatnik R-05 s Odjela za radiologiju (Tablica 1) koji je 2011. godine primio efektivnu dozu u iznosu od $700 \mu \mathrm{Sv}$, odnosno samo 0,7 mSv. Ukupno primljena efektivna doza istog djelatnika za kontrolni interval ujedno je i najveća (Tablica 1) od svih izloženih djelatnika te iznosi $946 \mu S v$, odnosno 0,95 mSv.

Ukupno primljena doza u cijelom kontrolnom intervalu za svih 111 djelatnika iznosi tek $13036 \mu$ Sv, odnosno 13,04 mSv.

Rezultati istraživanja ukazuju na činjenicu da niti jedan djelatnik nije bio ozračen prosječno od 20 mSv u jednoj godini, kao niti 100 mSv u razdoblju od pet uzastopnih godina. Dapače, primljene efektivne doze za izložene djelatnike izrazito su niske.

Iz toga slijedi da je ostvaren cilj istraživanja, odnosno da se hipoteza u eksperimentu pokazala istinitom, ali i da su primljene doze za svakog izloženog djelatnika u općoj bolnici daleko niže od granice izlaganja koja je propisana zakonskim odredbama. 


\section{ZAKLJUČAK}

Učinci ionizirajućeg zračenja na ljudski organizam uzrokovani velikim dozama u kratkom vremenu relativno su dobro poznati, no to se ne može tvrditi i za posljedice dugoročnog izlaganja malim dozama. S druge strane, primljene doze za izložene djelatnike u općoj bolnici toliko su niske da su praktički zanemarive.

Ako se ne poduzmu adekvatne mjere zaštite, sve to predstavlja potencijalnu opasnost u smislu ugrožavanja čovjekove životne i radne okoline.

Brojna iskustva iz prošlosti koja su rezultirala ozračivanjem pojedinaca, opasnost za život i zdravlje te zagađenje okoliša ukazala su na potrebu sustavne i organizirane provedbe mjera zaštite od ionizirajućeg zračenja. Svaka državna zajednica mora imati obvezu izgradnje kvalitetnog i uređenog sustava zaštite od zračenja na svim razinama društvenog ustrojstva.

Glavni indikator ovih pozitivnih rezultata istraživanja jest izrazito dobra implementacija zaštite od zračenja u ustanovi. Za pravilnu funkcionalnost sustava zaštite od zračenja potrebni su stručnjaci iz raznih područja što takav posao čini vrlo kompleksnim i odgovornim.

Ovaj rad potvrdio je učinkovitost primjene mjera i postupaka zaštite od ionizirajućeg zračenja na primljenu dozu za izložene djelatnike tijekom petogodišnjeg razdoblja što je rezultat sinergijskog djelovanja svake karike u tom sustavu.

\section{LITERATURA}

Brumen V., Franić, Z., Garaj-Vrhovac V.: Ionizirajuće zračenje, Medicinska naklada, Zagreb, 2002.

Dodig D., Ivančević D. i Popović S., ur.: Radijacijske ozljede: dijagnostika i liječenje, Medicinska naklada, Zagreb, 2002.

Hebrang A., Klarić-Čustović R., ur.: Radiologija, Medicinska naklada, Zagreb, 2007.

Institut za medicinska istraživanja i medicinu rada: Analiza rizika opće bolnice, 2015.

Novaković, M.: Zaštita od ionizirajućeg zračenja: propisi u Republici Hrvatskoj s komentarima, Ekoteh-dozimetrija d.o.o. za zaštitu od zračenja, Zagreb, 2001.

Pravilnik o granicama ozračenja, N.N., br. 59/13.

Pravilnik o mjerenju osobnog ozračenja, ispitivanja izvora ionizirajućeg zračenja i uvjeta rada te o izvještajima i očevidnicima, N.N., br. 41/12., 89/13.

Pravilnik o poslovima s posebnim uvjetima rada, N.N., br. 5/84.

Pravilnik o zdravstvenim uvjetima izloženih radnika i osoba koje se obučavaju za rad s izvorima ionizirajućeg zračenja, N.N., br. 80/13.

Suljić-Beganović, F. et al.: Jonizirajuće zračenje u medicini: zračenje u medicini, Bilten ljekarske komore, br. 19, 2015., str. 35-39.

Tončev, N.: Opasnosti i zaštita od jonizirajućeg zračenja, Institut za dokumentaciju zaštite na radu, Niš, 1977.

Turner, J.: Atoms, Radiation, and Radiation Protection, WILEY-VCH Verlag $\mathrm{GmbH} \&$ Co. KgaA, Weinheim, 2007.

Zakon o radiološkoj i nuklearnoj sigurnosti, N.N., br. 141/13., 39/15.

Zakon o zaštiti na radu, N.N., br. 71/14., 118/14. 


\section{RECEIVED RADIATION DOSES FOR EXPOSED EMPLOYEES IN GENERAL HOSPITALS}

SUMMARY: Certain employees of general hospitals are exposed to radiation from diagnostic units while performing everyday tasks. Any adverse event that may occur because of improper implementation of the measures and principles of radiation protection represents social loss and a certain loss for the institution itself. The paper covers the research addressed to study the impact of using measures and principles of radiation protection on received dose for professionally exposed employees. The main research method used was the descriptive method with the aim to collect and process data and to obtain research results, while the source of research was the actual practical implementation of occupational safety. The experimental part was based on the observation during a period of five years in which the received doses of radiation were measured according to type of work assignments for each of 111 employees. The research results, which are shown in this paper, indicate that received radiation doses for exposed employees are in accordance with legislation, provided that everyone abides by the basic measures of protection and regulations relevant for the profession.

Key words: ionizing radiation, effects of ionizing radiation, ionizing radiation protection, ionizing radiation doses

Professional paper

Received: 2017-02-03

Accepted: 2017-12-20 